\title{
TRANSFORMASI FITRAH DALAM PERSPEKTIF MAQASHID AL-SYARI'AH
}

\author{
A Kumedi Ja'far \\ Universitas Islam Negeri Raden Intan Lampung \\ Email: komedjafar@yahoo.co.id \\ Agus Hermanto \\ Universitas Islam Negeri Raden Intan Lampung \\ Email: gusher.sulthani@radenintan.ac.id \\ Siti Nurjanah \\ Institut Agama Islam Negeri Metro \\ Email: siti.nurjanah@metrouniv.ac.id \\ DOI: $10.37876 /$ adhki.v3i1.42
}

\begin{abstract}
Lesbian, Gay, Bisexual and Transgender (LGBT), often a debate in the midst of globalization, both in the media and in online media, more so in Indonesia with the largest Muslim population in the world, both pro on the grounds of human rights (human rights) or gender. However, this discussion does not recede until here, but rather increasingly sticking out. The study in this study is, what is the view of maqasid al-Shari'ah towards LGBT in Indonesia? The benefit of this research is to know in depth and prove scientifically lgbt actions both normatively and juridically in Indonesia in the perspective of Maqashid al-Shari'ah. This research is a library reseach taken from some opinions of scholars' fiqh both classical and contemporary and the percentage of legislation in Indonesia, more articles that are pro against the LGBT movement. Bahkan MUI telah mengeluarkan Fatwa sejak 2014 Nomor 57 tentang keharaman tindakan LGBT dengan alasan tindakan yang menyalahi firah manusia dan merupakan perbuatan fahisyah. Begitu juga dalam Undang-Undang Nomor 1 tahun 1974 dan Kompilasi Hukum Islam dengan tegas menjelaskan bahwa perkawinan dilakukan oleh seorang laki-laki dan perempuan untuk membina keluarga yang sakinah. Even MUI has issued a Fatwa since 2014 Number 57 on the prohibition of LGBT actions on the grounds of actions that violate human firah and are fahisyah acts. Similarly, in Law No. 1 of 1974 and compilation of Islamic law expressly explains that marriage is performed by a man and a woman to foster a sakinah family.
\end{abstract}

Keywords: LGBT, Maqashid Syariah

\begin{abstract}
Abstrak
Lesbi, Gay, Bisexsual dan Transgender (LGBT), sering kali menjadi perdebatan di tengah globalisasi, baik di media tulis maupun di media online, lebih-lebih di Indonesia yang berpenduduk muslim terbesar di dunia, baik yang pro dengan alasan Hak Asasi Manusia (HAM) ataupun gender. Namun demikian, pembahasan ini tidaklah surut sampai disini, melainkan semakin mencuat. Yang menjadi kajian dalam penelitian ini adalah, bagaimanakah pandangan maqasid al-Syari'ah terhadap LGBT di Indonesia? Manfaat penelitian ini adalah untuk mengetahui secara mendalam dan membuktikan secara ilmiah terhadap tindakan LGBT baik secara normatif maupun yuridis di Indonesia dalam perspektif Maqashid al-Syari'ah. Penelitian ini merupakan library reseach yang diambil dari beberapa pendapat ulama' fikih baik klasik maupun kontemporer maupun peratuiran perundangundangan di Indonesia, lebih-lebih banyaknya artikel yang pro terhadap gerakan LGBT. Secara normatif dalam al-Qur'an dan hadist terutama norma agama bahwa LGBT merupakan tindakan yang melampaui batas dan merupakan tindakan fahisyah, yaitu perbuatan keji, baik secara logika maupun empirik, begitu juga secara yuridis, yaitu fikih, ada tiga bentuk perbuatan keji, yaitu zina
\end{abstract}


(hubungan biologis dengan orang yang tidak ada ikatan suami istri antara laki-laki dan perempuan, liwath (tindakan biologis yang dilakukan oleh laki-laki dengan laki-laki atau sering disebut sodomi) dan sihaq adalah tindakan biologis antara perempuan dengan sejenisnya, hal ini sangat dilarang dalam agama Islam, karena merupakan perbuatan fahisyah dengan hukuman maksimal mati. Bahkan MUI telah mengeluarkan Fatwa sejak 2014 Nomor 57 tentang keharaman tindakan LGBT dengan alasan tindakan yang menyalahi firah manusia dan merupakan perbuatan fahisyah. Begitu juga dalam Undang-Undang Nomor 1 tahun 1974 dan Kompilasi Hukum Islam dengan tegas menjelaskan bahwa perkawinan dilakukan oleh seorang laki-laki dan perempuan untuk membina keluarga yang sakinah.

Kata Kunci: LGBT, Maqashid Syariah, Fitrah

\section{Pendahuluan}

Lesbi, Gay, Bisexsual dan Transgender (LGBT), sering kali menjadi perdebatan di tengah globalisasi, baik di media tulis maupun di media online, baik yang pro terhadap LGBT maupun yang kontra. ${ }^{1}$ Secara normatif, baik al-Qur'an maupun hadist telah melarang tindakan LGBT, sebagaimana surat al-a'raf ayat 10, surat al-nahl ayat 54, al-Ankabut ayat 28 secara jelas memberikan informasi terhadap umat Nabi Luth, begitu juga secara yuridis, para ulama telah ber-ijma' terhadap LGBT, dengan alasan bahwa LGBT merupakan tindakan fahisyah (yaitu tindakan yang keji dan berdosa besar bagi pelakunya), atau juga sering disebut khabisah (perbuatan hina) karena tidak dapat diterima oleh logika akal sehat karena dianggap keluar dari fitrah dan secara empiris dibenci oleh seluruh Negara di dunia.. ${ }^{2}$

Secara normative, menurut Wahbah Zuhaili, Istilah fahisyah dapat didefinisikan dalam tiga pengertian, pertama, zina, yaitu hubungan antara laki-laki dan perempuan yang tidak adanya ikatan pernikahan, yang kemudian dibagi pada mihsan wa ghairu muhsan, muhsan diraja, dan gairu mihsan dicambuk seratus kali, kedua, liwath (homoseksual) yaitu hubungan antara laki-laki dengan laki-laki yang hukumannya adalah mati, ketiga sihaq (lesbi) dengan hukuman $t a^{\prime} z i$ ir oleh hakim setempat. ${ }^{3}$

Perbincangan LGBT tidak hanya dilingkup lokal, namun dilingkup nasional bahkan Internasional. PBB sendiri pernah resolusi tentang pengakuan atas hak-hak LGBT, termasuk kejahatan, kebencian, kriminalisasi homoseksualitas dan diskriminalisasi, pernyataan pada Dewan Hak Asasi Manusia Jinewa Swiss, Jum'at, 6 Juli 2017, terhadap Hak Asasi LGBT. ${ }^{4}$ Dari pernyataan itulah terdapat 78 Negara telah mendukung dan melegalkan LGBT di negaranya dengan alasan HAM dan gender, namun demikian, seteah WHO (Organisasi Kesehatan Dunia (World Health Organization/WHO) tidak lagi mengkategorikan transgender sebagai salah satu bentuk gangguan mental.

Pembaruan ini telah disetujui pada 25 Mei lalu. Karena itu, transgender tidak lagi masuk dalam gangguan mental di International Statistical Classification of Diseases and Related Health Problems (ICD-11), sebuah manual yang digunakan secara global

\footnotetext{
${ }^{1}$ Ermayani, Tri. "LGBT Dalam Perspektif Islam." HUMANIKA 17.2 (2017): 147-168.

2 Harahap, Rustam DKA. "LGBT di Indonesia: Perspektif hukum Islam, HAM, psikologi dan pendekatan mașlahaha." Al-Ahkam 26.2 (2016): 223-248.

${ }^{3}$ Wahbah Zuhaili, al-Fiq al-Isla wa Adillatuhu, (), h.

4 Yansyah, Roby, and Rahayu Rahayu. "Globalisasi lesbian, gay, biseksual, dan transgender (Lgbt): perspektif HAM dan agama dalam lingkup hukum di Indonesia." Law Reform 14.1 (2018): 132-146.
} 
untuk mendiagnosis penyakit. Melansir The Independent pada Selasa (11/6/2019), keputusan tersebut sesungguhnya sudah diumumkan oleh WHO. Namun, pemungutan suara yang diadakan oleh World Health Assembly baru dilakukan. Nantinya, dalam ICD-11 yang akan mulai berlaku pada 1 Januari 2022, gangguan identitas gender akan diganti dengan ketidaksesuaian gender dan tercantum di bawah bab mengenai kesehatan seksual, bukan gangguan mental. ${ }^{5}$

Keputusan tersebut mendapatkan apresiasi dari beberapa aktivis hak asasi manusia dan LGBT. Keputusan WHO menghapus gangguan identitas gender dari manual diagnostiknya akan memiliki efek membebaskan pada orang-orang transgender di seluruh dunia, kata Graeme Reid, direktur hak LGBT+ di Human Rights Watch. Mengutip Webmd, istilah ketidaksesuaian gender digunakan oleh WHO untuk menggambarkan orang-orang yang identitas gendernya berbeda dari gender yang melekat padanya saat lahir. WHO menyatakan, klasifikasi baru ini diharapkan bisa meningkatkan penerimaan sosial, serta memberikan akses bagi para transgender ke sumber daya kesehatan yang penting.

Di Indonesia yang berpenduduk muslim terbesar di dunia, baik yang pro dengan alasan Hak Asasi Manusia (HAM) ataupun gender. Isu-isu LGBT tidak hanya secara teoritis yang memang memelintir beberapa dalil normatif baik al-Qur'an maupun hadist, namun juga secara praktis telah banyak komunitas-komunitas yang sering beroperasi. ${ }^{6}$ Walaupun di Indonesia, melalui Majlis Ulama Indonesia (MUI) telah mengeluarkan fatwanya terhadap LGBT pada 31 Desember 2014 Nomor 57 tentang Lesbian, Gay, Sodomi dan Pencabulan, bahkan telah dibuat RUU LGBT yang dengan sengaja ingin melegalkannya di Indonesia walaupun tidak diterima kemudian ${ }^{7}$.

Ada beberapa kasus yang terjadi di Indonesia, antara lain; Pertama, Pada bulan Juli 2015 Menteri Agama tidak menerima LGBT karena norma agama menentang, Kedua, Pada Tahun 2014 Satpol PP selalu melakukan razia terhadap LGBT. Ketiga, Pada Tahun 2016 Human Right Watch mendesak pemerintah Indonesia untuk membela LGBT. Keempat, Pada Tahun 2017 du gay muda (usia 20 dan 23) dijatuhi hukuman cambuk di dpan public di Aceh. Kelima, Pada Mei tahun 2017141 orang gay ditangkap (di Jakarta) (Sauna gay Komunitas). Keenam, Pada tahun 2019 Rektor USU memberhentikan USU (Cerpen Lesbi). Ketujuh, Pada Tahun 2019 di Puntianak hari tari Sedunia Taman diGulis dibubarkan.

Telah banyak kajian terdahulu, diantaranya; Lesbian, gay, bisexual, and transgender healthm, People who are lesbian, gay, bisexual, or transgender (LGBT) are members of every community. They are diverse, come from all walks of life, and include people of all races and ethnicities, all ages, all socioeconomic statuses, and from all parts of the country. The perspectives and needs of LGBT people should be

5 Meisahrina, Nina. TENOR CONFIGURATION BY INDONESIAN OFFICIAL SPEECH RESPONSES TO LESBIAN, GAY, BISEXUAL AND TRANSGENDER (LGBT). Diss. UNIMED, 2016.

${ }^{6}$ Hamid, Nilwani. "Peran Muhammadiyah Dalam Menyikapi Fenomena LGBT dan Aliran Keagamaan Menyimpang." Tarbawi Khatulistiwa 2.1 (2016).

${ }^{7}$ Nirwanto, Gisela Dea. "Pembingkaian Berita Pro Kontra LGBT di Laman Topik Pilihan Kompas. com." Jurnal E-Komunikasi 4.1 (2016). 
routinely considered in public health efforts to improve the overall health of every person and eliminate health disparities. ${ }^{8}$

LGBT keberadaannya merupakan kodrat Ilahi yang harus diterima keberadaannya; pertama, Secara realita, baik di media sosial maupun media elektronik yang pro terhadap gerakan LGBT, kedua, adanya komunitas LGBT yang mengang keberadaannya exis sampai sekarang, ketiga, ada beberapa perusahaan yang pro terhadap LGBT, keempat, dibeberapa Negara sekuler, LGBT sudah mendapatkan legalitas, enam, adanya bentuk pengajian dan shalawatan yang dilakukan oleh para komunitas LGBT.

Perbincangan terhadap Komunitas LGBT sangatlah gencar, khususnya di media masa, secara normatif (al-Qur'an maupun al-sunnah) serta yuridis yaitu fikih telah tuntas membahas hal tersebut, namun justru dengan adanya dunia global justru semakin banyak artikel-artikel yang dengan sengaja menyebarkan kelegalan LGBT, dengan alasan hak Asasi manusia, dan gender, serta mempelintir penafsiranpenafsiran dari ayat al-Qur'an dan sunnah. Hal ini tentunya sangat berbahaya bagi generasi mellinial yang gemar terhadap dunia elektronik yang tidak dapat berfikir yang moderat, dengan banyaknya melihat tayangan, pemahaman miring, dan bahkan pornografi yang ditawarkan melaui media social yang semakin merajalela, maka tentunya dibutuhkan banyak artikel yang memperkuat pemahaman yang benar tentang kedudukan LGBT dalam Islam. ${ }^{9}$

Namun demikian, pembahasan ini tidaklah surut sampai disini, melainkan semakin mencuat. Yang menjadi kajian dalam penelitian ini adalah, bagaimanakah pandangan maqasid al-Syari'ah terhadap LGBT di Indonesia? Manfaat penelitian ini adalah untuk mengetahui secara mendalam dan membuktikan secara ilmiah terhadap tindakan LGBT baik secara normatif maupun yuridis di Indonesia dalam perspektif Maqashid al-Syari'ah. Penelitian ini merupakan bentuk penelitian pustka (library reseach) dengan menggali secara normatif-yuridis terhadap tindakan LGBT yang diambil dari beberapa pendapat ulama' fikih baik klasik maupun kontemporer maupun peratuiran perundang-undangan di Indonesia, lebih-lebih banyaknya artikel yang pro terhadap gerakan LGBT.

\section{Sejarah Lesbi, Gay, Bisexsual dan Transgender}

Dalam al-Qur'an, telah diceritakan kaum (umat) Nabi Luth, yang terkenal homoseksual. Mereka tidak mau mengawini perempuan, kecuali sangat gemar melakukan hubungan seks dengan sesama laki-laki. Tatkala Nabi Luth menawarkan beberapa orang perempuan cantik untuk dikawininya, maka mereka menolaknya dengan mengatakan: "Kami sama sekali tidak menginginkan perempuan, karena kami telah memiliki pasangan hidup yang lebih baik", yaitu laki-laki yang berfungsi sebagai teman hidup yang dapat membantu kelangsungan hidup kami, ia un bisa digunakan sebagai pelampias nafsu seksual. Oleh karena itu, ketika Nabi Luth didampingi oleh

${ }^{8}$ Youth, L. G. B. T. "Lesbian, gay, bisexual, and transgender health." (2014)

${ }_{9}^{9}$ Muttaqin, Imron. "Membaca strategi eksistensi LGBT di Indonesia." Raheema: Jurnal Studi Gender Dan Anak 3 (2016). 
para Malaikat utusan Allah yang bertampan pemuda rupawan, ia merasa cemas karena dirinya bahwa mereka itu adalam manusia biasa yang menemuinya.

Timbullah kecemasan nabi Luth, karena dibayangkannya bahwa temantemannya itu, yang menjadi rebutan bagi kalangan yang hebat diantara mereka, karena mereka sangat suka dengan pemuda-pemuda yang rupawan. Ia merasa bahwa gejolak yang ditimbulkan oleh kaumnya dalam hal tersebut sulit diatasinya dan pasti banyak menimbulkan pengorbanan jiwa, disamping itu, malu juga terhadap tamunya itu. ${ }^{10}$

Ada beberapa ayat yang menjelaskan tentang sifat-sifat kaum Nabi Luth, antara lain surat al-Syu'ara' ayat 165: "Mengapa kamu mendatangi jenis lelaki di antara manusia" (QS. al-Syu'ara': 165) "dan kamu tinggalkan isteri-isteri yang dijadikan oleh Tuhanmu untukmu, bahkan kamu adalah orang-orang yang melampaui batas". (QS. al-Syu'ara': 166). "Dan tatkala datang utusan-utusan Kami (para malaikat) itu kepada Luth, Dia merasa susah dan merasa sempit dadanya karena kedatangan mereka, dan Dia berkata: "Ini adalah hari yang Amat sulit"11 (QS. al-Hud: 77). "Dan datanglah kepadanya kaumnya dengan bergegas-gegas. dan sejak dahulu mereka selalu melakukan perbuatan-perbuatan yang keji. ${ }^{12}$ Luth berkata: "Hai kaumku, Inilah puteri-puteriku, mereka lebih suci bagimu, Maka bertakwalah kepada Allah dan janganlah kamu mencemarkan (nama)ku terhadap tamuku ini. tidak Adakah di antaramu seorang yang berakal?" (QS. al-Hud: 78). "Mereka menjawab: "Sesungguhnya kamu telah tahu bahwa Kami tidak mempunyai keinginan'tsterhadap puteri-puterimu; dan Sesungguhnya kamu tentu mengetahui apa yang sebenarnya Kami kehendaki." (QS. al-Hud: 89).

Pada dasarnya praktek homoseksual telah terjadi pada masa Nabi Luth dan sudah dipraktekkan oleh umatnya, hanya saja praktek lesbian dalam al-Qur'an tidak dijelaskan dan tidak terlihat keterangannya, namun pada era sekarang ini praktek lesbian dan homoseksual justru merajalela di kalangan masyarakat, baik di Negara sekuler yang sudah mengatur dalam undang-undang Negara ataupun dinegara lainnya yang mempraktekkan bahkan menuntut untuk dilegalitaskan dalam undangundang.

Praktek tersebut bahkan tidak dilarang dinegara sekuler, bahkan tidak dikatagorikan sebagai perbuatan asusila (melanggar tata susila). Kalaupun melarang, hanya untuk memberantas terjadinya beberapa macam penyakit yang sering terjadi akibat dari perbuatan homoseksual dan lesbian yang menimbulkan penyakit AIDS dan lainnya. Maka praktek homoseksual yang dilakukan oleh Negara barat (sekuler) yang kemudian merabah kenegara Timur dan beberapa negara lainnya dengan virus yang disebarkannya, baik melalui media sebagai tawarannya, maupun menggunakan pendanaan khusus yang dilakukan untuk melegalkan dan dijadikan sebagai undangundang resmi dalam suatu Negara, dengan tujuan merusak moral bangsa, dengan

\footnotetext{
${ }^{10}$ Mahjudin, Masa'il al-Fiqhiyyah, Op.Cit., h. 35-36

${ }^{11}$ Nabi Luth a.s. merasa susah akan kedatangan utusan-utuaan Allah itu karena mereka berupa pemuda yang rupawan sedangkan kaum Luth Amat menyukai pemuda-pemuda yang rupawan untuk melakukan homo sexual. dan Dia merasa tidak sanggup melindungi mereka bilamana ada gangguan dari kaumnya.

${ }^{12}$ Maksudnya perbuatan keji di sini Ialah: mengerjakan liwath (homoseksual).

${ }^{13}$ mereka tidak punya syahwat terhadap wanita
} 
berdalih demi melindungi hak asasi manusia. Penyebab al-GBT adalah; pertama, faktor keluarga, kedua, faktor lingkungan dan ketiga, faktor genetic. ${ }^{14}$

\section{Definisi Lesbi, Gay, Bisexsual dan Transgender}

Istilah lesbian berasal dari bahasa Yunani, yaitu nama sebuah pulau yang bernama Lesboss, dipulau tersebut, hidup seorang pahlawan bernama Sabo, dan wanita itulah yang pertama-tama gemar melakukan perbuatan ini. Dalam bahasa Arab, homoseksual disebut liwath yang pelakunya disebut al-luthiyyu, yang sering diartikan singkat oleh Banga Arab "al-rajul ya'ti al-rajul" (laki-laki yang mengumpuli sesamanya). Sedangkan lesbian berasal dari kata sahaq atau musahaqah, yang pelakunya disebut al-sahiq, yang diartikan singkat oleh Bangsa Arab dengan perkataan "al-mar'at ta'ti al-mar'at" (perempuan yang selalu mengumpuli sesamanya). ${ }^{15}$ Homoseksual dilakukan dengan cara memasukkan dzakar (penis). Kedalam dubur, sedangkan lesbian dilakukan dengan cara msturbasi (onani) satu sama lain, atau cara lain untuk mencapai organism. Misalnya menggunakan alat yang dapat digunakan bersamasama agar mencapai organisme (climax of the sex act). ${ }^{16}$

Gay atau sering dikenal istilah Homoseksual berasal dari bahasa inggris homosexual, yang berarti laki-laki yang senang berhubungan seks dengan sesamanya, ${ }^{17}$ yaitu hubungan seksual yang sama jenis kelaminnya, baik sesama wanita maupun sesama lelaki. Namun, homoseksual biasanya identik dengan hubungan laki-laki sesama jenis, istilah homoseksual juga sering disebut dengan istilah sodomi. Sedangkan hubungan seks antara perempuan disebut lesbian, atau sifat perempuan yang senang berhubungan seks dengan sesama pula. ${ }^{18}$

Maka pada dasarnya bahwa homoseksual adalah prilaku laki-laki yang melampiaskan hasrat seksualnya terhadap laki-laki, sedangkan lesbian adalah prilaku perempuan yang melampiaskan hasrat seksualnya terhadap perempuan juga. Ada beberapa sebab seseorang melakukan homoseksual atau lesbian, sebagai berikut;

Pertama, Menurut Marthiko, homoseksual terjadi karena pengalamanpengalaman masa kecil atau masa lampau tentang seks yang membekas dibawah sadarnya. Apa yang seseorang pernah alami tentang seks masa kecil, maka pengalaman itu akan terbenak pada jiwanya sampai dewasa.

Kedua, Menurut Ann Landers, homoseksual terjadi karena salah asuh dimasa kecilnya, atau perlakuan orang tua yang salah. Bisa jadi orang tua mengharapkan anak peremuan, sementara yang lahir adalah laki-laki, sehingga anak yang lahir laki-laki tersebut diperlakukan seperti anak yang diharapkan, yaitu perempuan. Akibatnya anak tersebut, cenderung mengembangkan pola tingkah laku dan sikap yang sesuai

\footnotetext{
${ }^{14}$ Ibid.

15 Abdul Majid, Masa'il Fiqhiyyah Membahas Masalah-Maslah Fikih yang Aktual, (Pasuruan: PT. Garoeda Bina Umat, 1993), h. 31-34

${ }^{16}$ Masjfuq Zuhdi, Masail Fiqhiyyah; Kapita Selekta Hukum Islam, (Jakarta: PT. Toko Agung, 1997), h. 42

${ }^{17}$ Mahjudin, Masa'il al-Fighiyyah, (Jakarta: Kalam Mulia, 2012), h. 34

18 M. Ali Hasan, Masa'lul Fighiyyah Haditsah pada Masalah-Masalah Kontemporer Hukum Islam, (Jakarta: PT. Raja Grafindo Persada, tt.), h. 58
} 
dengan perlakuan yang diterima dari orang tuanya. Pola tingkah laku dan sikap tersebut, kalau tidak dirubah, diterapi, akan terbawa hingga dia dewasa.

Ketiga, Tidak pernah seorang laki-laki atau perempuan memperhatikan lawan jenisnya. Hal ini terkadang menyebabkan ketidak mampuan dalam hubungan koitus (seksual) dengan lawan jenisnya. Bisa jadi perasaannya merasa takut atau tidak tahu bahkan bergetaran ketika berdekatan dengan lawan jenisnya, sedangkan hasrat seks tidak bisa dihindarkan.

Keempat, Menurut Dzakia Derajat, homoseksual itu terjadi karena pengaruh lingkungan. Seperti orang yang terpisah atau jauh dari lawan jenisnya, baik disebabkan oleh tugas, adat kebiasaan atau peraturan sangat keras, sehingga tidak berkesempatan untuk kenal dengan lawan jenisnya. Kelima, Menurut Cario, homoseksual adalah suatu gejala saraf yang berasal karena ada hubungan dengan orang-orang yang berpenyakit sraf. ${ }^{19}$

Biseksual yang berarti dua jenis kelamin khunsa "waria atau banci" 20 menurut Dede Oetomo, banci atau waria tidak merujuk sama sekali pada orientasi seksual manusia. Istilah waria atau banci merupakan lebel negatif untuk menunjuk prilaku dan identitas gender yang gagal, karena itu orang tua akan menyebut banci jika anaknya tidak bersikap wajar sesuai identitas gendernya. Dalam istilah fikih. ${ }^{21}$

Biseksualitas merupakan ketertarikan romantis, ketertarikan seksual, atau kebiasaan seksual kepada pria maupun wanita. Istilah ini umumnya digunakan dalam konteks ketertarikan manusia untuk menunjukkan perasaan romantis atau seksual kepada pria maupun wanita sekaligus. Istilah ini juga didefinisikan sebagai meliputi ketertarikan romantis atau seksual pada semua jenis identitas gender atau pada seseorang tanpa mempedulikan jenis kelamin atau gender biologis orang tersebut, yang terkadang disebut panseksualitas.

Biseksualitas adalah salah satu dari tiga klasifikasi utama orientasi seksual, bersama dengan heteroseksualitas dan homoseksualitas, yang masing-masing merupakan bagian dari Rangkaian kesatuan heteroseksual-homoseksual. Suatu identitas biseksual tidak harus memiliki ketertarikan seksual yang sama besar pada kedua jenis kelamin; biasanya, orang-orang yang memiliki ketertarikan pada kedua jenis kelamin tetapi memiliki tingkat ketertarikan yang berbeda juga mengidentifikasikan diri mereka sebagai biseksual. Biseksualitas umumnya dikontraskan dengan homoseksualitas, heteroseksualitas, dan aseksualitas.

Menurut MacDonald dalam Crooks \& Baur (2005), individu biseksual adalah individu yang dapat terlibat dan menikmati aktivitas seksual dengan kedua jenis kelamin, yaitu jenis kelamin yang sama dan jenis kelamin yang berbeda, atau mengetahui bahwa dirinya mau untuk melakukan hal tersebut. Kebanyakan biseksual tidak tertarik kepada wanita dan pria sama besarnya, dan terkadang berpindah-pindah fase ketertarikannya sepanjang waktu. Ada kalanya pada saat ini ia tertarik kepada wanita tetapi seminggu kemudian ia hanya tertarik kepada pria. Namun, ada pula beberapa biseksual yang berada pada kondisi statis. Artinya, sepanjang waktu ia

${ }^{19}$ Ajat Suderajat, Fikih Aktual, (Ponorogo: STAIN Ponorogo Press, 2008), h. 8-9

${ }^{20}$ Pius A. Partanto, Kamus Ilmiah Populer, (Surabaya: Arkola, 1994), h. 77

21 Dede Oetomo, Gender dan Seksual Orientation in Indonesia, in Fantasizing the Famine in Indonesia, (London: Routledge, 1999), h. 261 
mengalami ketertarikan terhadap pria dan wanita sama besarnya. Di dalam skala 0-6 orientasi seksual yang dibuat oleh Alfred C. Kinsey, biseksual umumnya berada di skala 1-5 secara stabil. Artinya, biseksual tidak memiliki ketertarikan secara eksklusif kepada salah satu jenis kelamin saja.

Dalam Crooks \& Baur (2005), biseksual dapat dibagi ke dalam beberapa kategori, antara lain: real orientation, transitory orientation, transitional orientation, dan homosexual denial. Pada real orientation, individu biseksual memiliki ketertarikan pada wanita dan pria sejak awal kehidupannya dan berlanjut hingga usia dewasa. Pada orientasi ini, individu mungkin saja terlibat secara aktif dalam hubungan seksual dengan lebih dari satu pasangan atau mungkin saja tidak dan akan selalu memiliki perasaan ketertarikan terhadap kedua jenis kelamin secara terus menerus. Pada transitory, biseksual tidak menjadi orientasi seksual dominan dari individu yang bersangkutan. Kondisi biseksual di sini merupakan keadaan temporer dan terjadi umumnya karena pengaruh dari lingkungan, misalnya seorang heteroseksual yang akhirnya memiliki ketertarikan terhadap individu dari jenis kelamin sama karena adanya kebutuhan seksual yang harus dipenuhi tetapi kondisi lingkungan tidak memungkinkan baginya untuk berhubungan dengan lawan jenis sehingga ia memutuskan untuk berhubungan dengan sesama jenis untuk mengurangi dorongan seksualnya, contohnya di penjara atau di boarding school yang diperuntukan bagi satu jenis kelamin saja.

Biseksual berorientasi transitional menunjukan bahwa biseksual merupakan satu fase yang harus dilewati karena adanya perubahan dalam preferensi seksual, misalnya heteroseksual menjadi homoseksual atau vice versa. Perubahan preferensi seksual yang terjadi adalah perubahan yang bersifat permanen, artinya seorang heteroseksual berubah menjadi homoseksual melalui sebuah tahapan biseksual tetapi kondisi homoseksual, atau orientasi seksual yang paling akhir, menjadi bagian dari identitas dirinya untuk jangka waktu yang panjang. Setelah berada pada orientasi seksual akhir, individu tersebut bukan lagi seorang biseksual ataupun seorang penganut orientasi seksual sebelumnya.

Orientasi yang terakhir merupakan penyangkalan atas ketertarikannya terhadap sesama jenis (homosexual denial). Individu-individu biseksual pada kategori ini umumnya berusaha untuk menghindari stigma negatif yang beredar di masyarakat mengenai penganut homoseksual. Bagi individu-individu homoseksual, individuindividu biseksual pada kategori ini mereka lihat sebagai seorang homoseksual yang kurang berusaha untuk mengidentifikasikan diri mereka sebagai homoseksual."

Berdasarkan acuan diagnosis psikologis dari American Psychiatric Association, homoseksual dan biseksual tidak lagi dikategorikan sebagai perilaku abnormal. Abnormalitas justru terjadi kalo si penganut homoseksual ato biseksual merasa tidak nyaman dan terus mencoba menyangkal preferensi seksualnya.

Dilihat dari segi normatif, perilaku homoseksual dan biseksual dapat dikategorikan sebagai perilaku sosial menyimpang. Sebenernya orientasi seksual ada lagi selain homoseksual, heteroseksual, sama biseksual. Namanya aseksual. Kalo aseksual si individu tidak memiliki ketertarikan sama sekali, baik secara fisik, emosional, maupun psikologis, terhadap salah satu maupun kedua jenis kelamin yang ada. 
Dalam al-Qur'an hanya menyebutkan dua jenis identitas laki-laki dan perempuan. Sementara dalam fikih menyebut empat varian; perempuan, laki-laki, khunsa (waria atau banci), yaitu yang memiliki kelamin ganda, umumnya mereka berpenampilan atau berdandan sebagai perempuan, dan mukhannits (laki-laki secara biologis namun mengidentifikai sebagai perempuan dan menginginkan pergantian kelamin) atau mukhanitsat (secara biologis laki-laki tapi tidak mau mengubah jenis kelamin mereka).

Manusia yang lahir dalam keadaan normal jenis kelaminnya baik sebagai pria maupun sebagai wanita, karena mempunyai alat kelamin satu berupa dzakar (penis) dan farj (vagina) yang normal, tidak diperkenankan ganti kelamin. Jadi dalam kontek ini adalah mengoperasi atau merubah jenis kelamin yang normal dari laki-laki menjadi perempuan atau sebaliknya. Hal itu dilakukan karena biasanya ketidak puasan seseorang karena disebabkan karena ketidak cocokan bentuk fisik dan kelamin dengan kejiwaan atau adanya ketidak puasan dengan alat kelamin yang dimilikinya, keadaan ini sering disebut dengan transeksualisme atau transgender. Ekspresi kejiwaan tersebut bisa dalam bentuk dandanan, gaya dan tingkah laku. ${ }^{22}$

Perkataan pergantian kelamin merupakan terjemahan dari bahasa inggris transeksual, karena memang operasi tersebut sasaran utamanya adalah mengganti kelamin seorang waria yang menginginkan dirinya menjadi perempuan. Padahal waria digolongkan sebagai laki-laki, karena ia memiliki alat kelamin laki-laki.

Maka dalam hal ini, dapatdiambil kesimpulan bahwa pergantian kelamin (transseksual) adalah seorang dokter ahli bedah plastik dan kosmetik untuk mengganti kelamin seorang laki-laki menjadi kelamin perempuan, melalui proses operasi. ${ }^{23}$

Dalam dunia kedokteran dikenal tiga bentuk operasi kelamin, yaitu; Pertama, Operasi pergantian jenis kelamin yang dilakukan terhadap orang yang sejak lahir memiliki kelamin normal. Kedua, Operasi perbaikan atau penyempurnaan kelamin yang dilakukan terhadap orang yang sejak lahir memiliki cacat kelamin, seperti penis atau vagina yang tidak berlubang atau tidak sempurna. Ketiga, Operasi pembuangan salah satu dari kelamin ganda yang dilakukan terhadap orang yang sejak lahir memiliki dua organ kelamin (penis dan vagina). ${ }^{24}$

\section{Hukum Pernikahan Lesbi, Gay, Bisexsual dan Transgender}

Praktek homoseksual dan lesbian diharamkan dalam al-Qur'an, karena hal ini adalah termasuk perbuatan zina. Maka dalam hal ini, Zainudin bin Abdil Aziz alMaribary mengatakan, al-Bahawiyyu berkata, para ahli hukum Islam berselisih pendapat dalam memberikan ganjaran kepada parktek homoseksual. Ada sekelompok ulama yang mengatakan bahwa pelakunya harus dihukum sebagaimana menjatuhkan ganjaran hukum perzinaan. Apabila pelakunya tergolong orang yang sudah pernah kawin, maka wajib dirajam. Dan apabila ia belum pernah kawin, maka ia harus didera sebanyak 100 kali. Penetapan inilah yang mencerminkan kedua pendapat Imam Syafi'i

\footnotetext{
${ }^{22}$ Ajat Suderajat, Fikih Aktual, (Ponorogo: STAIN Ponorogo Press, 2008), h.135

${ }^{23}$ Mahjudin, Masa'il Al-Fiqhiyyah Kasus-Kasus Aktual dalam Hukum Islam, (Jakarta: Kalam Mulia, 2012), h. 29

24 Setawan Budi Utomo, Fikih Aktual Jawaban Tuntas Masalah Kontemporer, (Jakarta: Gema Insani Press, 2002), h. 138-139
} 
ra., (qaul qadim dan qaul jadid). Dan pendapat ini juga menetapkan bahwa laki-laki yang dikumpuli oleh homo seksual, mendapat ganjaran dera sebanyak seratus kali atau dasingkan setahun; baik laki-laki maupun perempuan, yang pernah kawin maupun yang belum pernah. Ada juga sekolompok ulama berpendapat, bahwa pelaku homo seksual wajib dirajam, sekalipun ia belum pernah kawin. Ia termasuk pendapat Imam Malik dan Imam Ahmad bin Hanbal. Dan pendapat lain, Imam Syafi'i menetapkan bahwa pelaku dan orang-orang yang dikumpuli (oleh homoseksual dan lesbian) wajib dibunuh, sebagaimana keterangan dalam hadits.
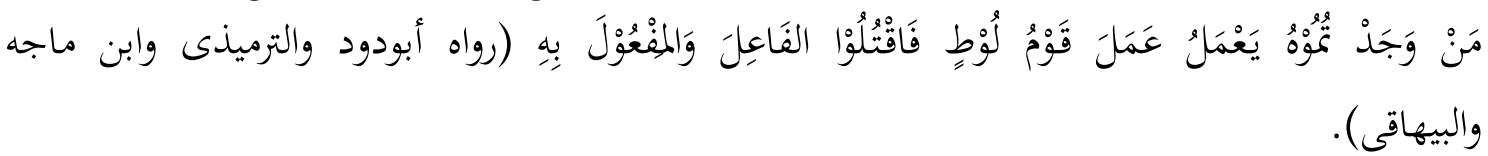

Artinya: "Barang siapa yang mendapatkan orang-orang yang melakukan perbuatan kaum Nabi Luth (praktek homoseksual dan lesbian), maka ia harus menghukum mati; baik orang yang melakukan maupun yang dikumpulinya". (HR. Abu Daud, al-Tirmidhi, Ibn Majah dan alBaihaqi).

Dalam hadits lain juga dikemukakan oleh Nabi:

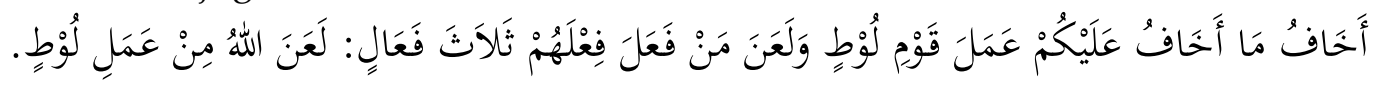

Artinya: "Sesuatu yang paling aku takuti atas kamu adalah perbuatan kaum Nabi Luth dan dilaknat mereka yang melakukan perbuatan seperti perbuatan mereka itu, Nabi mengulanginya sampai tiga kali".

Demikianlah para ulama telah sepakat mengharamkan hukum homo seksual dan lesbian. Walaupun mereka sepakat mengharamkan keduanya, perbedaan pendapat mereka ada pada hukuman bagi pelaksana homoseksual atau lesbian tersebut. ${ }^{25}$

Larangan homoseksual dan lesbian yang disamakan dengan perbuatan zina dalam ajaran Islam, bukan hanya karena merusak kemulyaan, dan martabat kemanusiaan, tetapi resikonya lebih jauh lagi; yaitu dapat menimbulkan kanker elamin, AIDS dan sebagainya. Tentusaja perkawinan waria yang telah menjalani operasi pergantian kelamin dengan laki-laki, dikatagorikan sebagai praktek homoseksual, karena tabiat laki-lakinya tetap tidak bisa dirubah oleh dokter, meskipun ia telah memiliki kelamin buatan. ${ }^{26}$

Berdasarkan hadits tersebut diatas, menurut Manziri bahwa Abu Bakar dan Ali pernah menghukum mati pasangan homoseksual. Pendapat lain al-Auza'i, Abu Yusuf, dan lain-lainnya, bahwa hukuman homoseksual disamakan dengan zina yakni hukuman dera dan pengusiran bagi yang belum kawin dan dirajam untuk pelaku yang sudah kawin. Hal ini berdasarkan suatu hadits Nabi:

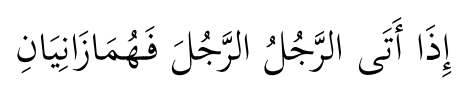

Artinya: "Apabila seorang pria mendatangi atau melakukan hubungan seksual dengan pria lain, maka keduanya adalah berbuat zina".

\footnotetext{
${ }^{25}$ Ajat Suderajat, Fikih Aktual, Op.Cit., h. 11-12

${ }^{26}$ Mahjudin, Masa'il al-Fiqhiyyah, Op.Cit., h. 40-41
} 
Pendapat Abu Hanifah, bahwa pelaku homosek dihukum ta'zir yakni suatu hukuman yang bertujuan edukatif dan berat ringannya diserahkan pada hakim. Misalnya dalam KUHP pasal 292 diancam dengan hukuman maksimal 5 tahun penjara. Menurut Syaukani, pendapat pertama adalah yang paling kuat, karena didukung oleh hadits shahih yang jelas maknanya, sedangkan pendapat kedua dianggap lemah karena memakai dalil qiyas, padahal ada nasnya.

Jadi hukum lesbian sama dengan hukum homoseksual, dan para ulama telah sepakat mengharamkannya berdasarkan hadits riwayat Ahmad, Ibnu Daud, Muslim dan Tirmidzi:

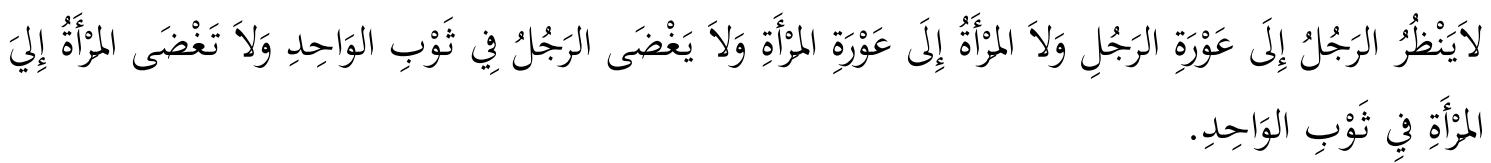

Menurut Sayyid Sabiq bahwa lesbian itu hukmnya ta'zir, yaitu hukuman yang berat ringannya diserahkan kepada hakim di Pengadilan. Jadi hukuman lesbian lebih ringan dari hukuman homoseksual, karena lesbiah hanyalah hubungan yang dilakukan dengan cara menggesek-gesekkan saja, namun hal ini diharamkan karena bertentangan dengan fitrah manusia. Homo memang lebih berat akibatnya daripada lesbian, karena homosek dilakukan dengan cara menusukkan dzakar kedalam dubur, dimana dubur tersebut adalah tempat keluarnya kotoran. ${ }^{27}$

Operasi dalam bentuk yang pertama, yaitu terhadap orang yang sejak lahir dalam kondisi normal dan sempurna organ kelaminnya, diharamkan oleh syari'ah Islam. Dalil yang dapat dijadikan dasar adalah:

Firman Allah dalam surat al-Hujarat ayat 13: "Hai manusia, Sesungguhnya Kami menciptakan kamu dari seorang laki-laki dan seorang perempuan dan menjadikan kamu berbangsa - bangsa dan bersuku-suku supaya kamu saling kenal-mengenal. Sesungguhnya orang yang paling mulia diantara kamu disisi Allah ialah orang yang paling taqwa diantara kamu. Sesungguhnya Allah Maha mengetahui lagi Maha Mengenal.

Menurut al-Thabari, ayat ini mengajarkan tentang keadilan bagi segenap manusia di hadapan Allah dan hukum yang masing-masing telah ditentukan jenis kelaminnya dan ketentuan Allah ini tidak boleh dirubah, setiap orang harus menjalani hidup sesuai dengan kodratnya. ${ }^{28}$

Firman Allah surat al-Nisa ayat 199: "dan aku benar-benar akan menyesatkan mereka, dan akan membangkitkan angan-angan kosong pada mereka dan menyuruh mereka (memotong telinga-telinga binatang ternak), lalu mereka benar-benar memotongnya, ${ }^{29}$ dan akan aku suruh mereka (mengubah ciptaan Allah), lalu benar-benar mereka meubahnya30". Barangsiapa yang menjadikan syaitan menjadi pelindung selain Allah, Maka Sesungguhnya ia menderita kerugian yang nyata".

${ }^{27}$ Ajat Suderajat, Fikih Aktual, Op.Cit., h. 13-14

${ }^{28}$ Masjfuk Zuhdi, Masa'il Fiqhiyyah: Kapita Selekta Hukum Islam, (Jakarta: PT. Toko Agung), h. 171

${ }^{29}$ Menurut kepercayaan Arab jahiliyah, binatang-binatang yang akan dipersembahkan kepada patung-patung berhala, haruslah dipotong telinganya lebih dahulu, dan binatang yang seperti ini tidak boleh dikendarai dan tidak dipergunakan lagi, serta harus dilepaskan saja.

${ }^{30}$ Meubah ciptaan Allah dapat berarti, mengubah yang diciptakan Allah seperti mengebiri binatang. ada yang mengartikannya dengan meubah agama Allah. 
Berdasarkan ayat di atas dalam beberapa tafsir disebutkan beberapa perbuatan manusia yang diharamkan karena termasuk "merubah ciptaan Allah", seperti mengebiri manusia, homoseksual, lesbian, menyambung rambut dengan sopak, pangur, membuat tato, mencukur bulu muka (alis) tan tahannus (seorang wanita bertingkah laku seperti laki-laki). ${ }^{31}$

Hadits Nabi riwayat Bukhari dan enam ahli hadits lainnya dari Ibnu Mas'ud ra:

$$
\text { لعن الله الواشمات والمستوشمات والنا مصات والمتنمصات والمتفلجات للحسن المغيرات خلق الله }
$$

Artinya: "Allah mengutuk para tukang tato, yang minta ditato, yang menghilangkan bulu muka, yang diminta dihilangkan bulu mukanya dan para wanita yang memotong (pangur) giginya, yang semua itu dikerjakan dengan maksud untuk kecantikan dengan mengubah ciptaan Allah".

Hadits Nabi yang diriwayatkan oleh Ahmad ra:

$$
\text { لعن الله المتشبهات من النّسآ بالرجال والمتشبهين من الرّجال بالنسآ }
$$

Artinya: "Allah mengutuk pria-pria yang menyerupai wanita-wanita dan wanita-wanita yang menyerupai pria".

Berdasarkan hadits di atas, seorang pria dan wanita yang lahir normal jenis kelaminnya dilarang oleh Islam mengubah jenis kelaminnya itu, karena mengubah ciptaan Allah tanpa alasan yang hak. Demikian pula seorang pria atau wanita yang kelaminnya normal, tetapi karena lingkungannya menderita kelainan semacam kecenderungan seksnya yang mendorong lahiriyahnya benci dengan berpakaian dan tingkah laku yang berlawanan dengan jenis lainnya. Maka dalam hal ini ia juga diharamkan oleh Agama mengubah jenis kelaminnya, sekalipun ia menderita kelainan seks. Karena kasus ini sebenarnya berakar dari kondisi kesehatan mental yang penanganannya bukan dengan mengubah ciptaan Allah, melainkan melalui pendekatan spiritual dan kejiwaan (spiritual psychological teraphy) bahkan menurut Yusuf Qordhawi, mengubah bentuk alami laki-laki menjadi perempuan atau sebaliknya, adalah menentang fitrah dan mengubah ciptaan Allah ini meruakan perbuatan setan yang justru menjadi musuh abadi manusia. ${ }^{32}$

Operasi dalam bentuk kedua dan ketiga disebut tashih atau takmil (perbaikan dan penyempurnaan) yang bukan mengganti jenis kelamin, menurut para ulama' dibolehkan secara hukum syari'ah Islam. Mengenai orang yang lahir tidak normal jenis kelaminnya, maka hukum melakukan operasi kelaminnya tergantung kepada keadaan organ kelamin luar dan dalam, dikelompokkan sebagai berikut:

1. Apabila seseorang mempunyai kelamin ganda, penis dan vagina, maka untuk memperjelas identitasnya, ia boleh melakukan operasi mematiak organ kelamin yang satu dan menghid upkan kelamin yang lainnya yang sesuai dengan organ kelamin bagian dalam.

2. Apabila seseorang mempunyai organ kelamin satu yang kurang sempurna bentuknya, misalnya ia mempunyai vagina yang tidak berlubang, sementara ia

${ }^{31}$ Masjfuk Zuhdi, Masa'il Fiqhiyyah, Op.Cit., h. 137

32 Yusuf Qordhawi, Fatwa-Fatwa Kontemporer, Penterjemah Samson Rahman, (Jakarta: Pustaka AlKautsar, 2001), h. 312 
mempunyai rahim dan ovarium, maka ia boleh dan bahkan dianjurkan oleh agama untuk melakukan operasi member lubang pada vaginanya. Begitu juga apabila memiliki penis dan testis, tetapi lubangnya tidak berada di ujung penisnya, namun dibagian bawahnya, maka iapun boleh melakukan operasi untuk dibuatkan lubang yang normal. Dalil syari'ah yang bisa dijadikan dasar diantaranya li jalbi al-mashalih wa li daf'i al-mafashid (untuk me ngambil maslahat dan menolak maslahat). ${ }^{33}$

Lebih lanjut Husain Muhammad Makhluf (tkoh ulama' Mesir) yang kitabnya Syahwat al-Bayan memberikan argumentasi hal tersebut, bahkan orang yang lahir dalam kelamin yang tidak normal bisa mengalami kelainan psikis dan sosial. Sehingga dapat tersisih dan mengasingkan diri dari kehidupan masyarakat normal dan kadang mencari jalannya sendiri seperti melacurkan diri menjadi waria atau melakukan homo seksual atau lesbian. Jadi, operasi ganti kelamin ini, perbaikan dan penyempurnaan, dilakukan berdasarkan prinsip maslahat mursalat. Selain itu secara umum tindakan operasi tersebut sesuai dengan hadits Nabi Riwayat Ahmad bin Hanbal dari Usamah yang memerintahkan agar hamba-hamba Allah bertaubat, karena tidak ada penyakit yang tidak dapat disembuhkan kecuali tua.

Adapun status hukum orang telah menjalani operasi jenis kelamin, maka tergantung kepada sifat dan tujuan operasi kelamin yang dilakukan. Apabila operasi kelamin itu dilakukan dengan tujuan ta'bid dan takhyir (mengganti dan merubah ciptaan Allah), maka identitasnya sama dengan sebelum operasi dan tidak merubah dari segi hukumnya.

Menurut Mahmud Saltut, dari segi kewarisan seorang wanita yang operasi melakukan pergantian kelamin menjadi pria tidak akan menerima warisan pria, demikian juga sebaliknya. Demikian juga dalam perkawinan tidak shah perkawinannya bagi orang yang telah (pernah) melakukan operasi ganti organ kelamin dengan tujuan di atas. ${ }^{34}$

Menurut fatwa MUI dalam musyawarah nasional ke II tahun 1980 tentang operasi perubahan atau pergantian kelamin, sekalipun diubah jenis kelamin yang semula normal, namun tetap kedudukan hukum jenis kelaminnya sama dengan jenis kelamin semula sebelum dirubah. ${ }^{35}$

Adapun operasi kelamin yang dilakukan pada seorang yang mengalami kelainan (misalnya kelamin ganda) dengan tujuan maslahat atau takmil (perbaikan atau penyempurnaan) dan sesuai dengan hukum, maka akan membuat identitas dan status hukum yang tersebut menjadi jelas.

Menurut Wahbab Zuhaili, jika selama ini penentuan jumlah waris bagi orang yang punya kelamin ganda (khunsa), maka setelah perbaikan kelamin menjadi pria atau wanita, hak waris dan status hukumnya menjadi jelas. Bahkan seyogyanya ia mengajukan permohonan ke lembaga Pengadilan untuk melegitimasi atas status jenis kelaminnya yang baru untuk menghindari konflik yang mungkin terjadi dalam

${ }^{33}$ Setiawan Budi Oetomo, Figh Aktual Jawaban Tuntas Masalah Kontemporer, (Jakarta: Gema Insani Press), h. 173-174

${ }^{34}$ Ajat Suderajat, Op.Cit., h. 140

${ }^{35}$ Ajat Suderajat, Op.Cit., h. 140 
perkawinan dan kewarisan. Konsekuwensinya, ia boleh melakukan perkawinan dengan pasangan yang berbeda jenis kelaminnya. ${ }^{36}$

Perubahan status hukum dari waria menjadi wanita atau pria setelah operasi perbaikan kelamin dapat dibenarkan oleh Islam karena alasan sebagai berikut; Pertama, Allah hanya menjadiakan manusia dua, yaitu laki-laki dan perempuansebagaimana disebutkan dalam al-Qur'an surat al-Hujarat ayait 13. Kedua, Hadits Nabi:

$$
\text { أمرت أن أحكم بالظواهر و الله يتولى السرائر }
$$

Artinya: "Aku diperintahkan memutuskan hukum berdasarkan fakta-fakta yang tampak, sedangkan Allah yang mengetahui segala rahasia".

Alasan Indonesia menolak LGBT adalah sebagai berikut: 1) Indonesia merupakan Negara yang beragama, artinya tidak ada satu agamapun di Indonesia yang mengajarkan tentang kebolehan LGBT, 2) Indonesia sangat beragam suku dan budaya, sehingga tidak ada satu suku dan budayapun yang menerima terwujudnya LGBT, 3) LGBT merupakan prilaku yang sangat menyimpang, karena tidak sesuai dengan nilai-nilai moral bangsa Indonesia, 4) LGBT merupakan penyakit kejiwaan, 5) LGBT dapat menular kepada siapa saja yang selalu berada dan bergaul dengan komunitas tersebut.

Ada beberapa faktor yang mempengaruhi LGBT, pertama, Tidak percaya pada Tuhan, karena ia selalu merasa bersalah dan terdiskriminalisasi serta merasa bahwa Tuhan telah melaknatnya, dalam hatinya merasa bahwa perbuatan itu adalah salah, namun ia merasa belum mendapatkan hidayat, kedua, keluarga yang memberi kebebasan pada anaknya, keluarga adalah orang yang paling bertanggung jawab terhadap anaknya, sehingga aktifitas anak haruslah tetap dijaga agar tidak terjerumus pada lembah hitam, ketiga, trauma terhadap kekecewaan pada lawan jenis, hal ini sering terjadi, karena telah gagal berkali-kali dengan lawan jenisnya, kemudian pustasi dan masuk dalam lembah hitam, keempat, ejekan yang diterima terus menerus sejak masa dini, kelima, kekaguman berlebohan ada orang lain, ketujuh, hidup bergaul dengan LGBT, kedelapan, ingin popular dan tinggi, kesembilan, faktor ekonomi, kesepuluh, faktor pengaruh kapita;isme, kesepuluh, tidak mampu mengendalikan nafsu sesat, kesebelas, jadi perempuan toboy dan laki-laki tomboy, kesebelas, sudah terbisa, sehingga terbiasa, keduabelas, tidak pernah disentuh, sehingga mudah terangsang.

Ada beberapa bahaya LGBT adalah; pertama, haus pengakuan, kedua, hubungan yang tidak direstui oleh pemerintah dan agama, ketiga, beresiko menyebabkan penyakit, keempat cenderung gonta-ganti pasangan, kelima, biasanya prilaku menjadi ateis, kelima, biasanya menjadi ateis, keenam, gila akan terbutuhinya, ketujuh, beberapa dijauhi oleh keluarga, kedelapan, komunkitas, temannhya melulu itu-itu saja, kesembilan, beberapa lahan pekerjaan kurang menerim terhadap keberadaan KGBT, kesepuluh, rentang stress.

Ada beberapa sikap yang harus dilaukan adalah; 1) menjaga pergaulan, 2) menutup celah pornografi, 3) mengadakan seminar-seminar terkait LGBT agar

${ }^{36}$ Ibid., h. 140 
masyarakat banyak wawasan, 4) Adanya Undang-Undang tentang LGBT, 5) diadakan bentuk-bentuk penyuluhan.

Maqasid al-syari'ah dalam mencermati LGBT adalah; pertama, menjaga agama, LGBT merusak agama, yaitu sebagaimana kisah Nabi Luth, tidak punya Tuhan (imanya lemah). Kedua, menjaga jiwa, bahwa LGBT merupakan penyakit jiwa yang sangat berbahaya bagi seseorang, dan bahkan bisa dianggap gangguan jiwa. Ketiga, menjaga akal, LGBT tidaklah dapat diterima oleh logika normal (tidak logis), keempat, menjaga nasab, LGBT tidak berketurunan, namun merusak generasi, maka orang tua haruslah menjaga anak-anaknya agar tidak melakukan pergaulan bebas, kelima, menjaga harta, sebagian besar pekerjaan atau lahan pekerjaan tidak dapat menerimanya, trans sex, operasi kelamin dan bahkan melakukan bentuk hubungan bebas.

\section{Dampak Lesbi, Gay, Bisexsual dan Transgender}

Dampak homoseksual dapat terjadi pada dirinya sendiri maupun masyarakat. Dampak negatif yang terjadi di masyarakat, disebutkan oleh Roshfi sebagaimana disebutkan oleh Masyfuq Zuhdi dalam kitabnya al-Islam wa al-tib adalah sebagai berikut:

1. Seorang laki-laki tidak tertarik pada wanita, tapi justru tertarik kepada lawan jenisnya, akan mengakibatkan penderitaan bagi isterinya kalau si homo kawin. Karena, perkawinan yang berupa akad, tidak semata-mata untuk menyalurkan hasrat seksual, tetapi untuk status sosial agar dia (si homo) diakui oleh masyarakat sebagai manusia normal. Bila si homo itu nikah (dengan motif seperti ini), maka akan mengakibatkan isterinya menjadi korban dan merana. Tentu isterinya akan berselingkuh dengan laki-laki lain yang notabenenya adalah berbuat zina yang dilarang agama.

2. Ada kelainan kejiwaan akibat mencintai sesame jenis kelamin, yaitu jiwanya tidak stabil dan timbul tingkah laku yang aneh-aneh. Prilaku demikian itu dalam kadar tertentu akan dapat meresahkan masyarakat.

3. Adanya gangguan saraf otak yang akibatnya dapat melemahkan daya piker dan semangat. Dengan kondisi tersebut dia tidak akan hidup produktif, tetapi malasmalas, bahkan dalam kondisi tertentu bisa menjadi beban keluarga.

4. Akibat penyakit AIDS yang menyebabkan penderitanya kekurangan daya tubuh.

Sedangkan dampak kepada keadaan kejiwaan dan akhlak si homo akan menjadi negatif berupa; Pertama, Kegoncangan batin, karena ia merasa ada kelainan perasaan terhadap dirinya, yaitu perasaannya sebagai wanita, tetapi organ tubuhnya laki-laki. Kedua, Depresi mental yang menyebabkan ia suka menyendiri, mudah tersinggung dan tidak dapat merasakan kebahagiaan hidup, karena kebahagiaan hidup pada intinya menjalankan kehidupannya secara normal. Ketiga, Karena ada kegoncangan batin, perasaan cemas dan sebagainya, maka keadaan daya pikirnya akan menimbulkan suatu sindrom atau himpunan gejala penyakit mental yang disebut hernesia.

George Harvard, dalam bukunya "Revolusi Seks": "kita tidak terlalu takut terhadap bahaya nuklir yang mengancam kehidupan manusia di abad modern ini. Yang kita khawatirkan adalah serangan seks yang setiap saat meledak menghancurkan 
moral manusia". Pandangan seperti ini dilontarkan juga oleh Arnold Toynbee yang menyatakan: "Dominasi seks dewasa ini akan mengakibatkan runtuhnyaperadaban manusia". ${ }^{37}$

\section{Kesimpulan}

Secara normatif dalam al-Qur'an dan hadist terutama norma agama bahwa LGBT merupakan tindakan yang melampaui batas dan merupakan tindakan fahisyah, yaitu perbuatan keji, baik secara logika maupun empirik, begitu juga secara yuridis, yaitu fikih, ada tiga bentuk perbuatan keji, yaitu zina (hubungan biologis dengan orang yang tidak ada ikatan suami istri antara laki-laki dan perempuan, liwath (tindakan biologis yang dilakukan oleh laki-laki dengan laki-laki atau sering disebut sodomi) dan sihaq adalah tindakan biologis antara perempuan dengan sejenisnya, hal ini sangat dilarang dalam agama Islam, karena merupakan perbuatan fahisyah dengan hukuman maksimal mati.. Bahkan MUI telah mengeluarkan Fatwa sejak 2014 Nomor 57 tentang keharaman tindakan LGBT dengan alasan tindakan yang menyalahi firah manusia dan merupakan perbuatan fahisyah. Begitu juga dalam Undang-Undang Nomor 1 tahun 1974 dan Kompilasi Hukum Islam dengan tegas menjelaskan bahwa perkawinan dilakukan oleh seorang laki-laki dan perempuan untuk membina keluarga yang sakinah.

\section{Daftar Pustaka}

Abdul Majid, Masa'il Fiqhiyyah Membahas Masalah-Maslah Fikih yang Aktual, Pasuruan: PT. Garoeda Bina Umat, 1993

Ajat Suderajat, Fikih Aktual, Ponorogo: STAIN Ponorogo Press, 2008

Ajat Suderajat, Fikih Aktual, Ponorogo: STAIN Ponorogo Press, 2008

Dede Oetomo, Gender dan Seksual Orientation in Indonesia, in Fantasizing the Famine in Indonesia, London: Routledge, 1999

Ermayani, Tri. "LGBT Dalam Perspektif Islam." HUMANIKA 17.2 (2017): 147-168.

Harahap, Rustam DKA. "LGBT di Indonesia: Perspektif hukum Islam, HAM, psikologi dan pendekatan mașlahah." Al-Ahkam 26.2 (2016): 223-248.

Hamid, Nilwani. "Peran Muhammadiyah Dalam Menyikapi Fenomena LGBT dan Aliran Keagamaan Menyimpang." Tarbawi Khatulistiwa 2.1 (2016).Muttaqin, Imron. "Membaca strategi eksistensi LGBT di Indonesia." Raheema: Jurnal Studi Gender Dan Anak 3 (2016).

Mahjudin, Masa'il al-Fiqhiyyah, Jakarta: Kalam Mulia, 2012

Mahjudin, Masa'il Al-Fiqhiyyah Kasus-Kasus Aktual dalam Hukum Islam, Jakarta: Kalam Mulia

Masjfuk Zuhdi, Masa'il Fiqhiyyah: Kapita Selekta Hukum Islam, Jakarta: PT. Toko Agung, 2012

M. Ali Hasan, Masa'lul Fiqhiyyah Haditsah pada Masalah-Masalah Kontemporer Hukum Islam, Jakarta: PT. Raja Grafindo Persada, tt.

\footnotetext{
37 Sudirman, Studi tentang Homoseksual menurut Pandangan Islam, dalam Chuzaimah T. Yanggo, Problematika Hukum Islam Kontemporer, buku ke-2, (Jakarta: LSIK Firdaus, 1996), h. 80
} 
Masjfuq Zuhdi, Masail Fiqhiyyah; Kapita Selekta Hukum Islam, Jakarta: PT. Toko Agung, 1997

Meisahrina, Nina. TENOR CONFIGURATION BY INDONESIAN OFFICIAL SPEECH RESPONSES TO LESBIAN, GAY, BISEXUAL AND TRANSGENDER (LGBT). Diss. UNIMED, 2016.

Nirwanto, Gisela Dea. "Pembingkaian Berita Pro Kontra LGBT di Laman Topik Pilihan Kompas. com." Jurnal E-Komunikasi 4.1 (2016).Pius A. Partanto, Kamus Ilmiah Populer, Surabaya: Arkola, 1994Setawan Budi Utomo, Fikih Aktual Jawaban Tuntas Masalah Kontemporer, Jakarta: Gema Insani Press, 2002

Sudirman, Studi tentang Homoseksual menurut Pandangan Islam, dalam Chuzaimah T. Yanggo, Problematika Hukum Islam Kontemporer, buku ke-2, Jakarta: LSIK Firdaus, 1996

Setiawan Budi Oetomo, Fiqh Aktual Jawaban Tuntas Masalah Kontemporer, Jakarta: Gema Insani Press

Yansyah, Roby, and Rahayu Rahayu. "Globalisasi lesbian, gay, biseksual, dan transgender (Lgbt): perspektif HAM dan agama dalam lingkup hukum di Indonesia." Law Reform 14.1 (2018): 132-146.Yusuf Qordhawi, Fatwa-Fatwa Kontemporer, Penterjemah Samson Rahman, Jakarta: Pustaka Al-Kautsar, 2001 